\title{
PENGARUH VARIASI AGREGAT KASAR PENYUSUN BETON TERHADAP KERAPATAN BETON DENGAN MENGGUNAKAN TRANSMISSION TIME PADA ALAT UPV (ULTRASONIC PULSE VELOCITY)
}

\author{
Fatma Dora Indriani $^{1 *}$, Christin Remayanti Nainggolan ${ }^{2}$, Ming Narto Wijaya ${ }^{2}$ \\ ${ }^{1}$ Mahasiswa Program Studi Sarjana / Jurusan Teknik Sipil / Universitas Brawijaya \\ ${ }^{2}$ Dosen / Jurusan Teknik Sipil / Universitas Brawijaya \\ *Korespondensi : fatmadora@ymail.com
}

\begin{abstract}
To find out the quality of concrete, we need to test the concrete. Which is non destructive test or testing without damaging the test object, namely with an UPV (Ultrasonic Pulse Velocity). In this study using 4 variations of coarse aggregate composition (mix design), namely porous variation, RCA (Recycled Coarse Aggregate) variation, pumice variation and fiber variation. The UPV test results in this study show that the relationship of compressive strength with amplitude (A1) or transmission time (tO) is concluded that the low homogeneity value causes higher energy loss so the amplitude value becomes lower and the value transmission time depends on the density of the concrete. In the value of compressive strength that affects homogeneity, it does not mean the higher the uniform material (homogeneity), the higher the compressive strength value.
\end{abstract}

Keywords: Amplitude, Concrete, Compressive Strength, Ultrasonic Pulse Velocity, Transmission Time

\section{PENDAHULUAN}

Kekuatan tekan beton dapat diuji dalam dua cara, destruktif dan non destruktif. Cara destruktif adalah pengujian yang sifatnya merusak benda uji sedangkan pengujian cara non destruktif dilakukan tanpa merusak benda uji, pelaksanaannya dapat dilakukan di tempat kerja (insitu).

Tes UPV (Ultrasonic Pulse Velocity) adalah cara untuk mengetahui kekuatan beton, yang didasarkan pada hubungan kecepatan gelombang UPV melalui media beton dengan kualitas beton itu [1]. Alat tersebut mampu mengetahui waktu transmisi dan amplitudo gelombang melalui beton dengan memperlihatkan bentuk gelombang (waveform) secara digital. Dari data waktu transmisi dan amplitudo gelombang tersebut dapat ditunjukkan bagaimana kerapatan, homogenitas, serta ada tidaknya rongga di dalam beton.

Pada penelitian ini digunakan variasi penyusun agregat kasar yang beragam, dari variasi penyusun agregat kasar tersebut dapat dibuktikan hubungan antara kuat tekan beton dan Transmission Time pada jenis variasi agregat kasar tersebut.

\section{TINJAUAN PUSTAKA}

\subsection{Recycled Coarse Aggregate}

Beton agregat kasar daur ulang atau biasa disebut Recycled Concrete Aggregates (RCA) adalah agregat yang terbentuk dari proses pengukuran, pemecahan, pemilihan, dari sebuah beton keras yang terlebih dulu sudah ada. Limbah beton tersebut dihancurkan dengan mesin penghancur lalu diayak sehingga nantinya akan didapatkan butiran agregat kasar sesuai yang kita harapkan.

\subsection{Beton Porous}

Beton porous bisa disebut juga sebagai previous concrete yaitu beton yang dapat tembus dan menggambarkan beton dengan nilai slump mendekati nol [2]. Campuran pada Previous concrete adalah air, semen, agregat kasar dan sedikit atau tanpa agregat halus yang nantinya akan membentuk suatu material tembus air [3]. 


\subsection{Batu Apung (Pumice)}

Batu apung merupakan batuan sedimen dari batuan vulkanis dengan berat yang ringan, karenakan banyaknya pori pada batu tersebut. Dikarenakan memiliki berat yang ringan, maka jika batu apung digunakan sebagai agregat kasar pada beton, maka akan menghasilkan berat beton yang ringan [4].

\subsection{Beton Fiber Kaleng}

Beton serat didefinisikan sebagai beton yang terbuat dari campuran semen, agregat halus, agregat kasar dan sejumlah kecil serat/fiber [5]. Beton serat adalah bahan komposit yang terdiri dari beton biasa dan bahan lain yang berupa serat. Serat dalam beton berguna untuk mencegah adanya retak - retak sehingga menjadikan beton dengan serat lebih daktail dari beton normal.

\subsection{Pengujian UPV}

Dengan melakukan pengujian UPV adalah cara untuk memperkirakan kekerasan beton yang didasarkan pada hubungan cepatrambat gelombang melalui media beton dengan kekuatan tekan beton itu [1]. Pengujian UPV dilakukan dengan mengukur kecepatan perambatan gelombang elektromagnetik longitudinal yang melalui media beton.

UPV atau metode kecepatan pulsa ultrasonik tentunya dapat digunakan untuk mengevaluasi kualitas dari beton dan dapat digunakan untuk mendeteksi retak internal dan cacat lainnya pada beton, termasuk perubahan dari beton seperti penurunan kualitas beton akibat berbagai kondisi, misalnya lingkungan kimia yang agesif atau pembekuan dan pencairan. Kecepatan gelombang ultrasonik dipengaruhi oleh kekuatan beton dan kekakuan elastis pada beton dengan kondisi pemadatan yang kurang baik, atau mengalami kerusakan pada butiran material, gelombang UPV akan mengalami penurunan kecepatan. Perubahan kekuatan beton pada tes UPV ditunjukkan

dengan perbedaan kecepatan pada gelombangnya. Jika kecepatan naik, maka kekuatan beton meningkat dan sebaliknya, jika kecepatan beton turun, maka beton akan mengalami penurunan kekuatan.

$$
\text { Ultrasonic Pulse Velocity (UPV) }
$$

merupakan salah satu metode non destructive test dengan menggunakan gelombang ultrasonik yang didasari pengukuran waktu tempuh gelombang. Waktu tempuh gelombang dibaca oleh pengukur waktu pada UPV dan nantinya ditampilkan dalam bentuk kecepatan gelombang. Cara kerja UPV pada dasarnya mengirim getaran gelombang pada beton dan menerima getaran untuk selanjutnya dihitung lama waktu tempuh perambatan getaran gelombang tersebut [6]. Kecepatan gelombang akan ditampilkan oleh alat uji UPV berdasarkan waktu tempuh yang telah dihitung. Pengujian efektif menggunakan metode UPV adalah ketika beton sudah berusia lebih dari 3 hari, karena kecepatan gelombang akan sangat dipengaruhi oleh kondisi beton.

\subsection{Prinsip Analisis Bentuk Gelombang}

Prinsip analisis gelombang yang digunakan yaitu dengan membandingkan bentuk gelombang dari pengujian beton eksisting dengan beton yang menjadi acuan dengan mutu yang tentunya dapat diterima [7]. Parameter yang di ambil adalah waktu transmisi $\left(t_{0}\right)$ dan tingkat penerimaan dari receiver berdasarkan amplitudo dari puncak pertama gelombang yang diterima $(A 0)$.

Selanjutnya adalah pengujian pada bagian struktur yang ingin diketahui mutunya untuk mendapatkan dua parameter di atas yaitu to dan Ao pada beton eksisting seperti pada Gambar 1. Parameter tersebut nantinya akan dibandingkan dengan nilai hasil pengujian pada beton acuan. Sehingga mendapatkan kesimpulan mengenai mutu beton eksisting yang diuji tersebut. Beberapa interpretasi dari hasil pengujian dapat dilihat pada Gambar 2.

Hasil dari pembacaan waktu transmisi dapat diperoleh homogenitas dan kerapatan dari beton. Gelombang lebih cepat merambat melalui bagian yang memiliki kerapatan yang tinggi atau dengan rongga yang sedikit/kecil, seperti beton dengan jumlah agregat kasar (kerikil) banyak atau beton bertulang. Sedangkan amplitudo menunjukkan tingkat kehilangan energi dari gelombang yang diterima oleh receiver yang dipengaruhi oleh perubahan ukuran dan kerapatan partikel yang dilalui. Pada beton yang tersusun dari butiran yang relatif seragam (misalnya beton dengan jumlah pasir yang tinggi) kehilangan energi cenderung lebih rendah sehingga mengakibatkan amplitudo yang terbaca menjadi lebih tinggi. 


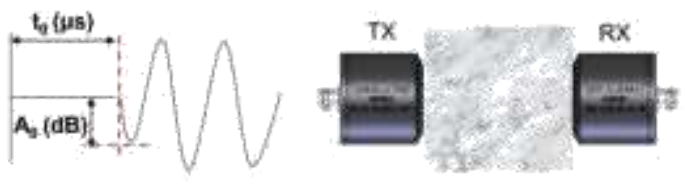

Gambar 1. Bentuk Gelombang dari Beton Acuan Telah Diketahui Mutunya (Sumber: PROCEQ, 2014)
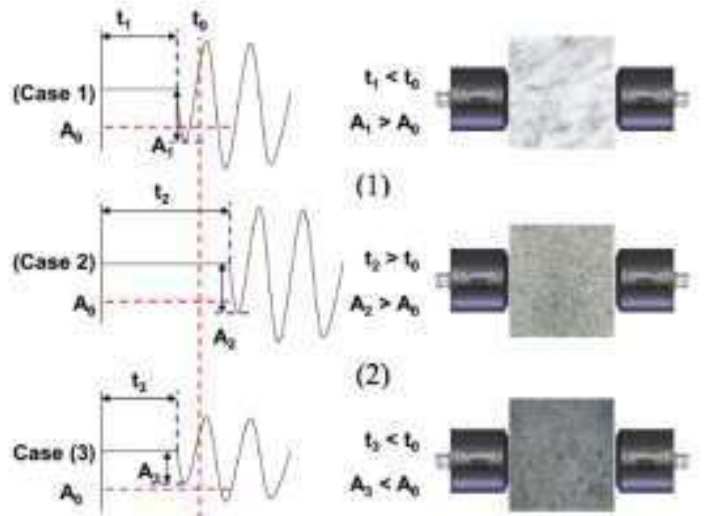

(1)

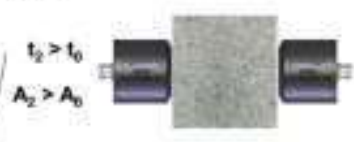

(2)
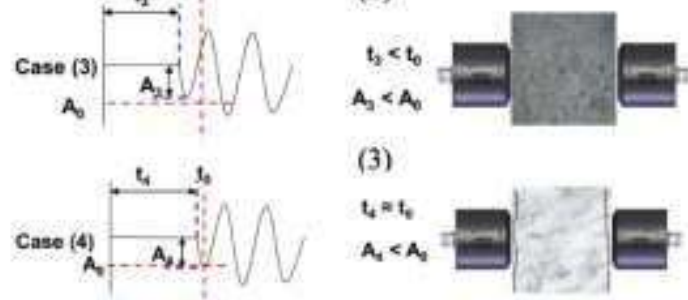

(3)

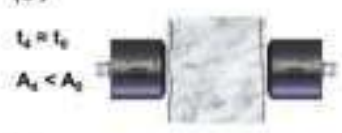

(4)
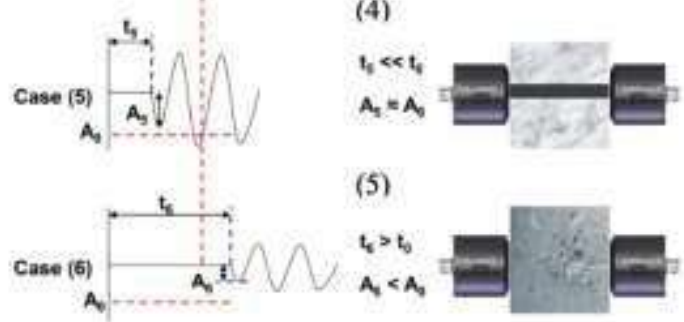

(5)

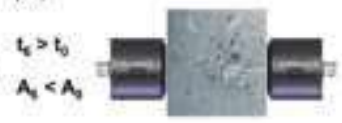

(6)

Gambar 2. Perbandingan Parameter Beton yang Diuji dengan Beton Acuan. (1) Beton dengan kualitas baik dan kekuatan tinggi, (2) jumlah pasir yang tinggi dan kerikil rendah, (3) jumlah kerikil tinggi dan pasir rendah, (4) retak permukaan atau pemberian couplant yang buruk, (5) pengujian melalui tulangan, dan (6) terjadi retak, honeycomb, atau rongga. (Sumber: PROCEQ, 2014)

\section{METODOLOGI PENELITIAN}

Penelitian ini dilakukan di Laboratorium Struktur dan Bahan Konstruksi Jurusan Teknik Sipil Fakultas Teknik Universitas Brawijaya, Malang dimulai pada bulan Mei 2018 sampai selesai. Penelitian menggunakan 36 benda uji silinder dengan diameter $15 \mathrm{~cm}$ dan tinggi 30 $\mathrm{cm}$. Benda uji dibedakan menjadi 4 variasi komposisi agregat kasar campuran beton (mix design) yaitu Variasi Porous dengan mutu beton rencana $14 \mathrm{Mpa}$, Variasi RCA (Recycled Coarse Aggregate) dengan mutu beton rencana 20 Mpa, Variasi Pumice dengan mutu beton rencana 17 Mpa dan Variasi Fiber dengan mutu beton rencana $17 \mathrm{Mpa}$.

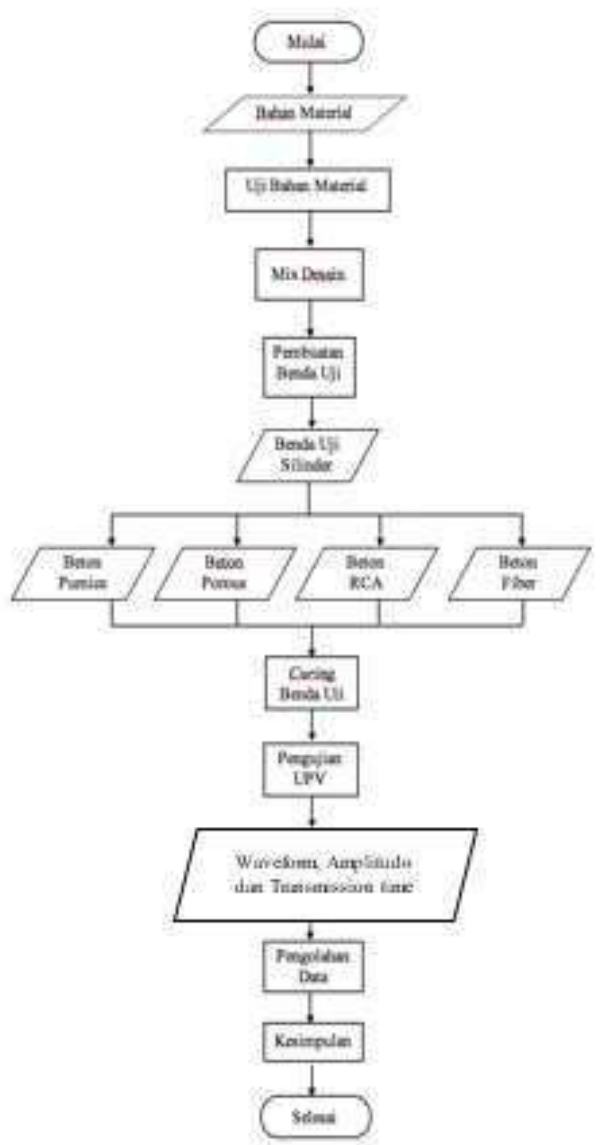

Gambar 3. Diagram Alir Penelitian

\section{HASIL PENELITIAN DAN PEMBAHASAN}

\subsection{Beton Variasi Porous}

Tabel 1. Kebutuhan Bahan untuk Campuran Benda Uji Beton Variasi Porous

\begin{tabular}{|c|c|c|c|c|c|}
\hline Beton & $\begin{array}{c}\text { Sem } \\
\text { en }\end{array}$ & Air & $\begin{array}{c}\text { Agregat } \\
\text { Halus }\end{array}$ & $\begin{array}{c}\text { Agregat } \\
\text { Kasar }\end{array}$ & Ket. \\
\hline $\begin{array}{l}\text { Porous } \\
\text { Normal }\end{array}$ & 1 & 0,4 & - & 8,4 & - \\
\hline Porous 1 & 1 & 0,4 & - & 9,1 & $\begin{array}{c}\text { Silica } \\
\text { Fume } \\
7 \%\end{array}$ \\
\hline Porous 2 & 1 & 0,6 & - & 11,3 & $\begin{array}{l}\text { Fly } \\
\text { Ash } \\
25 \%\end{array}$ \\
\hline $\begin{array}{l}\text { Porous } \\
\text { Recycle }\end{array}$ & 1 & 0,4 & - & 7,6 & $\begin{array}{l}\text { RCA } \\
25 \%\end{array}$ \\
\hline
\end{tabular}




\subsection{Beton RCA}

Tabel 2. Kebutuhan Bahan untuk Campuran Benda Uji Beton Variasi RCA

\begin{tabular}{cccccc}
\hline Beton & Semen & Air & $\begin{array}{c}\text { Agregat } \\
\text { Halus }\end{array}$ & $\begin{array}{c}\text { Agregat } \\
\text { Kasar }\end{array}$ & Ket. \\
\hline Recycle & 1 & 0,6 & 1,7 & 1,9 & $\begin{array}{c}\text { Agregat } \\
\text { Kasar RCA } \\
100 \%\end{array}$
\end{tabular}

\subsection{Beton Variasi Pumice}

Tabel 3. Kebutuhan Bahan untuk Campuran Benda Uji Beton Variasi Pumice

\begin{tabular}{|c|c|c|c|c|c|}
\hline Beton & $\begin{array}{c}\text { Sem } \\
\text { en }\end{array}$ & Air & $\begin{array}{c}\text { Agregat } \\
\text { Halus }\end{array}$ & $\begin{array}{l}\text { Agrega } \\
\text { t Kasar }\end{array}$ & Ket. \\
\hline $\begin{array}{l}\text { Pumice } \\
\text { Normal }\end{array}$ & 1 & 0,6 & 2,1 & 3,2 & $\begin{array}{c}25 \% \\
\text { pumice }\end{array}$ \\
\hline $\begin{array}{l}\text { Pumice } \\
\text { Fiber } \\
\text { Normal }\end{array}$ & 1 & 0,5 & 2,1 & 2,4 & $\begin{array}{l}25 \% \\
\text { pumice, } \\
\text { fiber } \\
\text { kaleng } \\
10 \%\end{array}$ \\
\hline $\begin{array}{l}\text { Pumice } \\
\text { Pilin A }\end{array}$ & 1 & 0,5 & 2,1 & 2,4 & $\begin{array}{c}25 \% \\
\text { pumice, } \\
\text { fiber } \\
\text { kaleng } \\
10 \% \\
\text { dipilin } 1 \mathrm{x}\end{array}$ \\
\hline $\begin{array}{l}\text { Pumice } \\
\text { Pilin B }\end{array}$ & 1 & 0,5 & 2,1 & 2,4 & $\begin{array}{c}25 \% \\
\text { pumice, } \\
\text { fiber } \\
\text { kaleng } \\
10 \% \\
\text { dipilin } 1,5 \mathrm{x}\end{array}$ \\
\hline
\end{tabular}

\subsection{Beton Variasi Fiber}

Tabel 4. Kebutuhan Bahan untuk Campuran Bahan Uji Beton Variasi Fiber

\begin{tabular}{lccccc}
\hline Beton & $\begin{array}{c}\text { Sem } \\
\text { en }\end{array}$ & Air & $\begin{array}{c}\text { Agregat } \\
\text { Halus }\end{array}$ & $\begin{array}{c}\text { Agrega } \\
\text { t Kasar }\end{array}$ & Ket. \\
\hline $\begin{array}{l}\text { Fiber } \\
\text { Normal }\end{array}$ & 1 & 0,5 & 2,1 & 2,9 & $\begin{array}{c}\text { Fiber } \\
\text { Kalen } \\
\text { g } 10 \%\end{array}$ \\
\hline $\begin{array}{l}\text { Fiber } \\
\text { Kait }\end{array}$ & 1 & 0,5 & 2,1 & 2,9 & $\begin{array}{l}\text { Fiber } \\
\text { Kalen } \\
\text { g } 10 \%\end{array}$ \\
\hline
\end{tabular}

\subsection{Pengujian Kuat Tekan Beton}

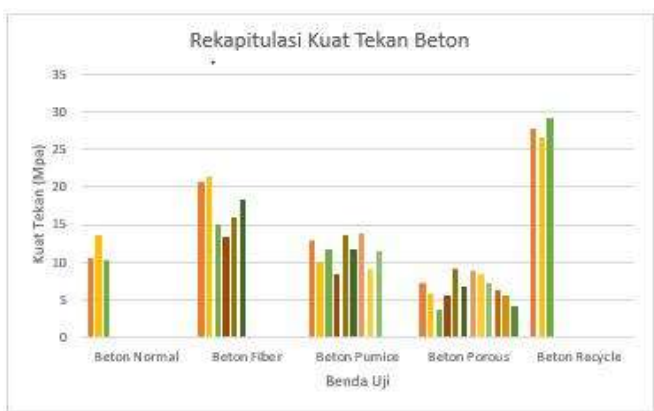

Gambar 4. Hasil Pengujian Kuat Tekan
Kesimpulan hasil dari pengujian kuat tekan menunjukan bahwa kuat tekan beton aktual sebagian besar hasilnya lebih kecil dari kuat tekan rencana dengan kuat tekan rata - rata sebesar 17,43 MPa pada beton variasi Fiber; 6,53 Mpa pada beton variasi Porous; 11,37 MPa pada beton variasi Pumice; 27,86 MPa pada beton variasi Recycle. Hal tersebut dapat disebabkan akibat proses pengerjaan beton yang kurang sempurna baik pada proses pengadukan hingga proses vibrasi berlangsung.

\subsection{Pengujian UPV}

Parameter yang di ambil pada pengujian UPV adalah (1) t0 dan A0 yaitu waktu dan amplitudo gelombang pertama terdeteksi beton yang menjadi acuan, (2) t1 dan A1 yaitu waktu dan amplitudo gelombang pertama beton, (3) tmaks dan Amaks yaitu waktu dan amplitude gelombang saat kondisi maksimum dan (4) t2 dan A2 yaitu waktu dan amplitude gelombang ketika terjadi pergantian fase gelombang pertama. Untuk sample Beton Normal sebagai acuan didapatkan t0 sebesar $75,9 \mu$ s dan A0 sebesar $5,1 \%$, s edangkan untuk sample Fiber Kait sebagai pembanding didapatkan $\mathrm{t} 1$ sebesar 78,9 $\mu$; A1 sebesar 3,5\%; tmaks sebesar 241,3 $\mu \mathrm{s}$; Amaks sebesar 17,9\% ; t2 sebesar 153,3 $\mu \mathrm{s}$; A2 sebesar $51,5 \%$.

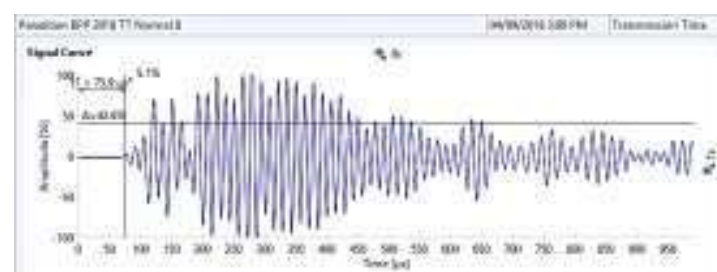

Gambar 5. Pengambilan Parameter t0 dan A0 Beton Acuan

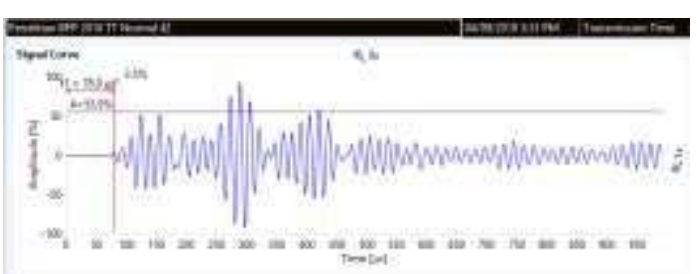

Gambar 6. Contoh Pengambilan Parameter t1 dan A1 Beton Pembanding 


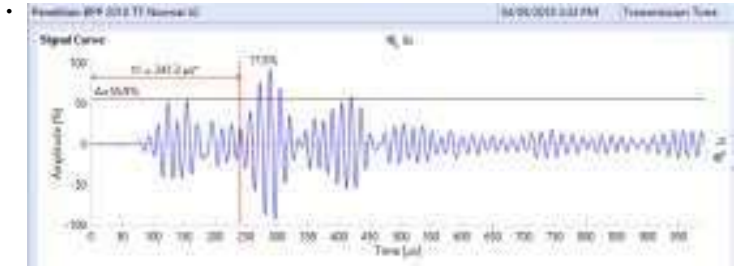

Gambar 7. Contoh Pengambilan Parameter 2 dan A2 Beton Pembanding.

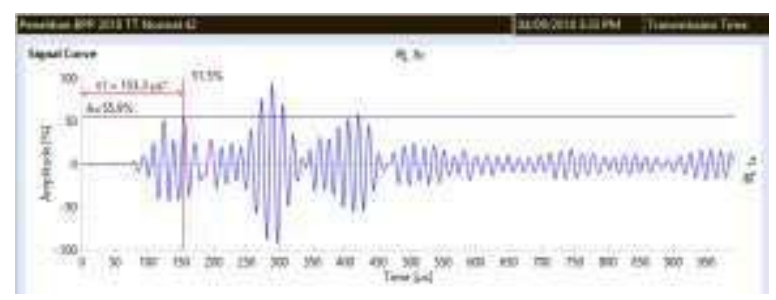

Gambar 8. Contoh Pengambilan Parameter tmaks dan Amaks Beton Pembanding.

\subsection{Pengambilan Sample Beton Acuan}

Sampel yang dijadikan sebagai beton acuan yaitu sampel silinder dengan perbandingan mix design 1:2:3 (semen: agregat halus: agregat kasar) dengan nilai fas sebesar 0,6 dan fc' rata rata sebesar 13,52 MPa. Beton sample N1.2 pada proses pengecoran memiliki penyebaran gradasi agregat yang lebih baik.

Tabel 5. Rekapitulasi Data Parameter Waveform TT Beton Acuan

\begin{tabular}{|c|c|c|c|c|c|c|}
\hline \multirow{2}{*}{ No } & \multirow{2}{*}{$\begin{array}{c}\text { Nama } \\
\text { Sample }\end{array}$} & \multirow{2}{*}{ Kode } & \multicolumn{2}{|c|}{ Waktu $(\mu \mathrm{s})$} & \multicolumn{2}{|c|}{ Amplitudo (\%) } \\
\hline & & & to & Rata & A0 & Rata2 \\
\hline 1 & \multirow{9}{*}{ Normal } & N1.1 & 78,9 & \multirow{3}{*}{78,9} & 1,9 & \multirow{3}{*}{1,43} \\
\hline 2 & & & 78,9 & & 1 & \\
\hline 3 & & & 78,9 & & 1,4 & \\
\hline 4 & & $\mathrm{~N} 1.2$ & 75,9 & & 3,1 & \\
\hline 5 & & & 75,9 & 75,9 & 3,8 & 4 \\
\hline 6 & & & 75,9 & & 5,1 & \\
\hline 7 & & $\mathrm{~N} 1.3$ & 78,9 & & 1,5 & \\
\hline 8 & & & 78,9 & 78,9 & 1,6 & 1,7 \\
\hline 9 & & & 78,9 & & 2 & \\
\hline
\end{tabular}

\subsection{Pengukuran Beton Pembanding dengan Metode TT}

Setiap benda uji di rata - rata untuk didapatkan hubungan antara kuat tekan beton dengan parameter - parameter gelombang yaitu amplitudo dan transmission time. Perbandingan antara kuat tekan dan parameter gelombang disajikan dengan 12 benda uji tersebut.

\subsection{Hubungan antara Kuat Tekan Beton dengan Parameter Gelombang}

Setiap benda uji di rata - rata untuk didapatkan hubungan antara kuat tekan beton dengan parameter - parameter gelombang.

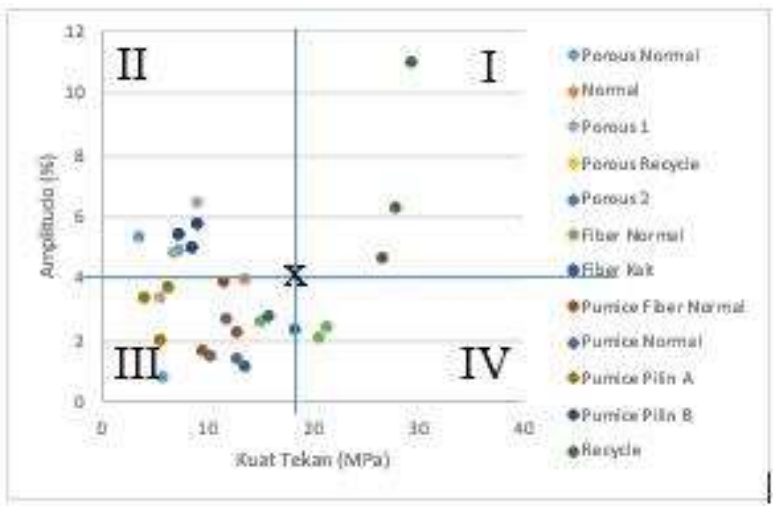

Gambar 9. Hubungan Kuat Tekan Beton dengan Amplitudo.

Dari Gambar 11 dapat diketahui bahwa nilai perbandingan antara amplitudo dan kuat tekan dan transmission time dan kuat tekan lebih banyak pada kuadran III yaitu bernilai $42 \%$ untuk amplitudo terhadap kuat tekan dan 44\% untuk transmission time terhadap kuat tekan. Sehingga dari data hasil pengujian benda uji dikatakan memiliki nilai amplitudo dan transmission time yang lebih rendah dari beton acuan dan nilai kuat tekan yang lebih rendah dari pada beton acuan.

Pada beton variasi porous dimana kondisi agregat dengan homogenitas yang relatif tinggi yaitu hanya menggunakan agregat kasar saja tanpa menggunakan agregat halus, nilai Amplitudo lebih besar dari beton acuan dan nilai transmission time lebih rendah dari beton acuan. Nilai kuat memiliki nilai yang lebih rendah dari beton acuan.

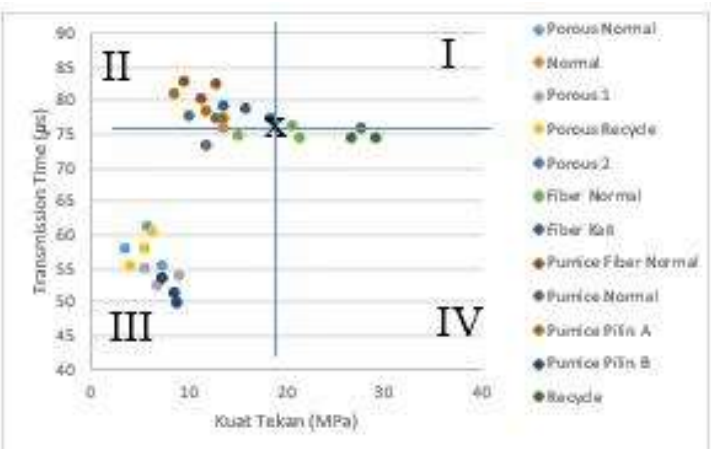

Gambar 10. Hubungan Kuat Tekan Beton dengan Transmission Time. 


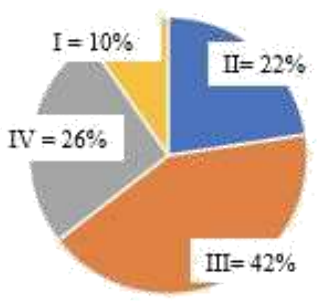

a)

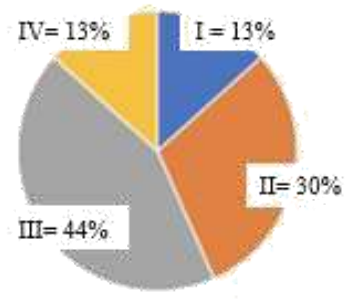

"b)
Gambar 11. Prosentase Sebaran Data disetiap Kuadran a) Amplitudo b) Transmission Time dengan Metode TT.

Pada beton variasi pumice baik pumice tanpa fiber maupun dengan fiber dimana kondisi agregat dengan homogenitas yang relatif lebih rendah yaitu terdapat agregat halus dan agregat kasar dengan agregat kasar berupa batuan pumice dengan tekstur berpori atau berrongga sehingga menyebabkan kehilangan energi yang besar, maka nilai Amplitudo lebih rendah dari beton acuan dan nilai transmission time lebih besar dari beton acuan. Nilai kuat tekan memiliki nilai yang lebih rendah dari beton acuan.

Pada beton variasi fiber normal dan kait dimana kondisi agregat dengan homogenitas yang relatif lebih rendah yaitu terdapat agregat halus dan agregat kasar dengan agregat kasar diberikan penambahan fiber dari serat baja, nilai Amplitudo lebih rendah dari beton acuan dan nilai transmission time lebih besar dari beton acuan. Dikarenakan nilai modulus elastisitas baja lebih besar dari modulus elastisitas beton. Nilai kuat tekan memiliki nilai yang lebih tinggi dari beton acuan.

Pada beton variasi RCA dimana kondisi agregat dengan homogenitas yang relatif lebih rendah yaitu terdapat agregat halus dan agregat kasar dengan agregat kasar berasal dari recycled agregat dengan mutu $\mathrm{K} 300$ hingga K350, nilai Amplitudo lebih tinggi dari beton acuan dan nilai transmission time hampir mendekati dengan nilai dari beton acuan. Nilai kuat tekan memiliki nilai yang lebih tinggi dari beton acuan.

Dari Gambar 9 dan Gambar 10 dapat disimpulkan bahwa hubungan kuat tekan beton dan amplitudo memiliki nilai yang beragam, tergantung pada komposisi beton itu sendiri.

Ketidakseragaman hasil pengukuran Amplitudo serta kuat tekan aktual yang lebih kecil dari kuat tekan rencana tersebut membuktikan bahwa sebagian besar benda uji beton pada penelitian ini memiliki homogenitas yang rendah. Nilai homogenitas yang rendah menyebabkan kehilangan energi lebih tinggi sehingga nilai amplitudo menjadi lebih rendah dan nilai transmission time menjadi lebih tinggi. Kemungkinan penyebabnya antara lain adanya rongga serta susunan agregat yang tidak seragam, yang merupakan faktor penting penunjang kekuatan dari beton. Sedangkan untuk nilai kuat tekan yang berpengaruh pada homogenitas yaitu bukan berarti semakin tinggi material yang seragam (homogenitas) maka menyebabkan nilai kuat tekan tinggi. Pada beton variasi porous karena terdapat rongga yang lebih banyak, maka menyebabkan nilai kuat tekan beton porous lebih rendah dari beton acuan.

\subsection{Hubungan Amplitudo dan Transmission Time}

Dengan penjelasan kuadran I hingga IV sebagai berikut: (Gambar 13)

1. Kuadran $\mathrm{I}=\mathrm{t} 1>\mathrm{t} 0$ dan $\mathrm{A} 1>\mathrm{A} 0$

2. Kuadran $\mathrm{II}=\mathrm{t} 1<\mathrm{t} 0$ dan $\mathrm{A} 1>\mathrm{A} 0$

3. Kuadran III $=\mathrm{t} 1<\mathrm{t} 0$ dan $\mathrm{A} 1<\mathrm{A} 0$

4. Kuadran $\mathrm{IV}=\mathrm{t} 1>\mathrm{t} 0$ dan $\mathrm{A} 1<\mathrm{A} 0$

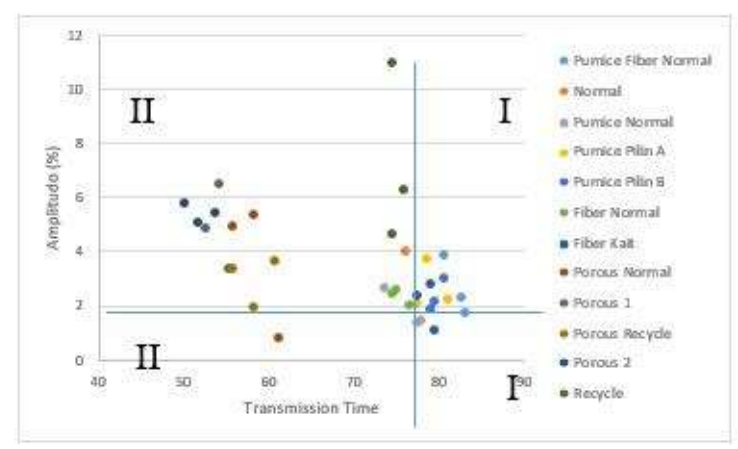

Gambar 12. Hubungan Amplitudo dengan Transmission Time.

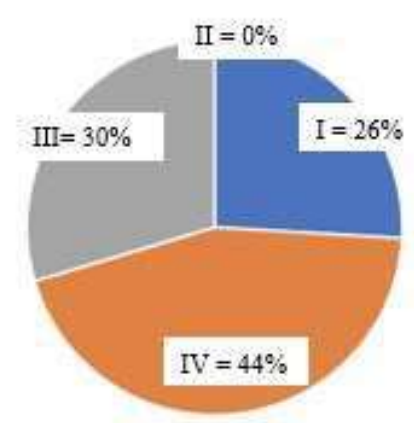

Gambar 13. Prosentase Sebaran Data disetiap Kuadran. 
Setelah dilakukan pengujian dan analisis bentuk gelombang, dapat diketahui bahwa benda uji beton memiliki kondisi sebagai berikut:

- Beton Variasi Fiber termasuk dalam Case 6 (Kuadran IV) yaitu $\mathrm{t} 1>\mathrm{t} 0$ dan $\mathrm{A} 1<\mathrm{A} 0$ beton dengan kondisi terjadi retak, honey comb atau rongga.

- Beton Variasi Porous termasuk dalam Case 3 (Kuadran III) yaitu $\mathrm{t} 1<\mathrm{t} 0$ dan $\mathrm{A} 1<\mathrm{A} 0$, beton dengan kondisi jumlah kerikil tinggi dan pasir rendah.

- Beton Variasi Pumice termasuk dalam Case 6 (Kuadran IV) yaitu $\mathrm{t} 1>\mathrm{t} 0$ dan $\mathrm{A} 1<\mathrm{A} 0$, beton dengan kondisi terjadi retak, honey comb atau rongga.

- Beton Variasi Recycle termasuk dalam Case $I$ (Kuadran I) yaitu $\mathrm{t} 1<\mathrm{t} 0$ dan $\mathrm{A} 1>\mathrm{A} 0$, beton dengan kondisi kualitas baik

dan kekuatan tinggi.

Adanya rongga maupun perbedaan partikel yang dilewati gelombang dapat menyebabkan difraksi atau refleksi serta mampu meredam energi yang dirambatkan oleh gelombang ultrasonik, sehingga mempengaruhi intensitas gelombang yang diterima oleh transduser. Pola kerapatan dan susunan agregat yang berbeda menyebabkan pola difraksi dan refleksi yang berbeda pula, sehingga akan mempengaruhi besarnya energi yang terbaca pada transduser.

\section{KESIMPULAN DAN SARAN \\ 5.1 Kesimpulan}

Dari hasil penelitian ini didapatkan kesimpulan sebagai berikut:

1. Dari hasil pengujian kuat tekan didapatkan hasil pengukuran kuat tekan compression test terhadap benda uji silinder yang digunakan dengan 4 variasi agregat kasar yang digunakan memberikan kuat tekan rata - rata sebesar 17,43 MPa pada beton variasi Fiber; 6,53 Mpa pada beton variasi Porous; $11,37 \mathrm{MPa}$ pada beton variasi Pumice; 27,86 MPa pada beton variasi Recycle. Sedangkan untuk hubungan kuat tekan dan amplitudo (A1) dan hubungan kuat tekan dan transmission time (t0) didapatkan kesimpulan bahwa nilai homogenitas yang rendah menyebabkan kehilangan energi lebih tinggi sehingga nilai amplitudo menjadi lebih rendah dan nilai kerapatan yang tinggi menyebabkan nilai transmission time menjadi lebih tinggi dikarenakan sedikitnya rongga pada beton tersebut. Pada nilai kuat tekan yang berpengaruh pada homogenitas yaitu bukan berarti semakin tinggi material yang seragam (homogenitas) maka menyebabkan nilai kuat tekan tinggi.

2. Dari hasil analisis antara kuat tekan dan parameter gelombang, didapatkan kesimpulan bahwa dengan dibandingkan dengan sampel beton acuan yang dianggap memiliki kerapatan yang seragam, didapatkan pola sebaran data dengan kesimpulan, beton variasi Fiber termasuk beton kategori terjadi retak, honeycomb atau rongga; beton variasi Porous termasuk beton kategori jumlah kerikil tinggi dan pasir rendah; beton variasi Pumice termasuk beton kategori terjadi retak, honeycomb atau rongga; dan beton variasi Recycle termasuk beton kategori kualitas baik dan kekuatan tinggi. Hal ini dikarenakan perambatan gelombang akan memiliki waktu transmisi yang lebih cepat pada beton yang memiliki kerapatan tinggi yang kemungkinan besar kuat tekannya juga tinggi. Sedangkan untuk nilai amplitudo masih belum menemukan hasil yang

konsisten karena ketidakseragaman komposisi dan susunan agregat yang menimbulkan pembacaan amplitudo yang berbeda-beda meskipun dalam satu sampel yang sama.

\subsection{Saran}

Terdapat beberapa saran dalam penelitian ini:

1. Pemberian cairan couplant pada saat pengujian $U P V$ harus dipastikan jumlah agar perataan pemberian couplant pada seluruh benda uji sama.

2. Perlunya menjaga kestabilan tranducer.

3. Perlunya kontrol yang lebih baik terhadap proses pencampuran beton dan komposisi material agar mencegah pengaruh dari faktor - faktor lain yang tidak diinginkan.

4. Pada pengambilan data analisis amplitudo dapat digunakan fitur Amplitude Marker dari alat PUNDIT PL-200 pada menu amplitude analysis, yang berfungsi untuk merekam data amplitudo awal secara otomatis. 


\section{DAFTAR PUSTAKA}

[1] International Atomic Energy Agency,Vienna. Guidebook on non-destructive testing of concrete structures, Training Course Series No. 17. 2002.

[2] Ginting, Arusmalem. Perbandingan Kuat Tekan dan Porositas Beton Porous Menggunakan Agregat Kasar Bergradasi Seragam Dengan Gradasi Menerus. Jurnal Sekolah Tinggi Teknologi Nasional 2017.

[3] Neville \& Brooks. Concrete technology, 442. 2010

[4] Hidayat, AN. Pengaruh Komposisi Agregat
Kasar(Breksi Batu Apung dan Batu Pecah) terhadap berat jenis dan Kuat Tekan Beton. Jurnal Mahasiswa Jurusan Teknik Sipil 2012.

[5] ACI Committee 544. State of the art report on fiber reinforced concrete - Report : ACI 544 IR - 82. Farmington Hills : American Concrete Institute. 1982.

[6] Malhotra, V.M. \& Carino, N.J. Handbook on Nondestructive Testing of Concrete. Boca Raton: CRC Press. 2004.

[7] PROCEQ. Pundit PL-200 and PE Ultrasonic Training. Switzerland : Proceq. 2014. 